\title{
Becoming an Aikidoka: Acculturation and Essentialism in the Practice of Aikido
}

\author{
Kevin Siah-Yeow TAN* \\ SIM University (Singapore)
}

Recepción: 10/07/2014; Aceptación: 08/12/2014; Publicación: 16/12/2014.

\begin{abstract}
Based on an ethnographic study conducted from 2002-2005 in Canada, this paper argues that the practice of Aikido within a specific community of practitioners does not simply exist as a medium for acquiring martial knowledge, but is also a viable conduit for acculturating or essentializing aspects of Japanese culture and identity. This is made possible in light of the highly embodied and corporeal dimension of Aikido practice, which requires one to develop the necessary dispositions and strategies for the construction of an Aikido habitus. Consequently, the path towards becoming an Aikidoka enables one to potentially embody, in similar but also unique ways, the cultural and moral worldviews that the art seeks to represent within intercultural and transnational spaces.
\end{abstract}

Keywords: Aikido; Martial Arts; Culture; Body; Habitus; Bourdieu.

\section{Llegar a ser un aikidoka: aculturación y esencialismo en la práctica del aikido}

\section{Resumen}

Basado en un estudio etnográfico realizado en Canadá entre 2002 y 2005, este artículo sostiene que la práctica del aikido en el seno de una comunidad específica de practicantes no existe simplemente como un medio de adquirir conocimientos marciales, sino que es también una forma viable para aculturizar o esencializar aspectos de la cultura e identidad japonesa. Esto es posible gracias a la dimensión altamente corporal y encarnada de la práctica del aikido, la cual exige al individuo desarrollar las disposiciones y estrategias necesarias para construir el habitus del aikido. Consecuentemente, el camino para llegar a ser un aikidoka posibilita al individuo encarnar potencialmente, de formas similares pero también únicas, las concepciones del mundo a nivel cultural y moral que este arte busca representar en espacios interculturales y transnacionales.

Palabras clave: Aikido; artes marciales; cultura; cuerpo; habitus; Bourdieu.

\section{Tornar-se um aikidoca: aculturação e essencialismo na prática do aikido}

\section{Resumo}

Baseado num estudo etnográfico, realizado no Canadá entre 2002 e 2005, este artigo sustém que a participação do aikidoca no seio de uma comunidade específica de praticantes não é simplesmente um meio de adquirir conhecimentos marciais, mas também uma forma viável para a aculturação e apreender aspectos da identidade japonesa. Isto é possível graças à dimensão altamente corporal e encarnada da prática do aikido, que exige ao indivíduo desenvolver as disposições e estratégias necessárias para construir o habitus do aikido. Conseqüentemente, o caminho para se ser um aikidoca possibilita ao indivíduo encarnar potencialmente formas similares, mas também únicas, ou seja, as concepções do mundo a nível cultural e moral que esta arte procura representar em espaços interculturais e transnacionais.

Palavras-chave: Aikido; artes marciais; cultura; corpo; habitus; Bourdieu.

\section{1.- Introduction}

The following paper is based on an ethnographic study of an Aikido community from 20022005 in the city of Calgary in Western Canada, conducted as part of my doctoral research in cultural

*Email: kevintan@unisim.edu.sg. Address: SIM University. 461 Clementi Road. Singapore, 599491. Tel: +65 62486109. 
anthropology. The community I worked with consisted of members of an Aikido dojo ${ }^{1}$, known as Clearwater Aikido Centre ${ }^{2}$. The Centre was headed by a high ranking instructor who was supported by a cadre of senior Aikido practitioners and had an estimated number of 200 members. A key objective of my study was to examine how active participation in martial arts such as Aikido can serve as a medium for the dissemination and transmission of cultural practices and worldviews, while simultaneously situated within a highly multi-cultural and globalized environment in Calgary, a major Canadian city.

In this paper, I argue that a martial art such as Aikido does not simply exist as a medium for acquiring martial knowledge, but possesses the potential to serve as a viable conduit for acculturating or essentializing aspects of Japanese culture and identity. All this is made possible by the highly embodied and corporeal dimension of Aikido practice, which inevitably requires one to gradually develop the necessary dispositions and strategies for the construction of an Aikido habitus (Bourdieu, 1990). In doing so, this implies the inscription and embodiment of not just the corporeal history of each practitioner, but also an intersecting relationship with the broader history of fighting and cultural practices situated within Aikido itself. Within the context of Clearwater Aikido Centre, this has led to the construction of intercultural identities among dedicated Aikido practitioners, which are further mediated and negotiated by its practitioners within a broader intercultural framework that is often strategic, multi-dimensional and multi-directional. In other words, the practice of Aikido is not simply the practice of martial technique, as it also enables one to become a 'body of culture', where aspects of Japanese cultural practices are newly acculturated or further heightened through the performative practices of a martial art.

The journey towards becoming an Aikidoka, or a practitioner of Aikido, is therefore a highly embodied one, similar to several other perspectives that have been increasingly examined by scholars in the fields of sports (Alter, 1992; Heiskanen, 2012; Light \& Kirk, 2000), performance arts (Foster, 1995) and martial arts (Jones, 2002), where highly developed forms of corporeality have a central, explicit focus. This is a reflection of just how much embodiment as a paradigm (Csordas, 1990, 2002) has gained increasing significance within the last few decades among social and cultural theorists (Mascia-Lees, 2011). In turn, this has also resulted in a surge of related ethnographic studies, largely because of their potential in articulating such phenomenon with detail and depth. One of the most influential has certainly been the seminal ethnographic study by Loïc Wacquant (2004) on boxers in a South Side Chicago gymnasium, which played a central role in claiming a growing scholarly space for social science researchers in martial arts or contact sports.

At the same time, this study of an Aikido community is part of a growing corpus of research on the role of the body in the construction of a habitus within performative cultures. Often defined by scholars in a variety of contexts as 'body culture' (Brownell, 1995), 'carnal sociology' (Crossley, 1995), an 'anthropology of human movement' (Farnell, 1999) or an 'anthropology of the senses' (Howes, 2003), such scholarly work recognizes how social life possesses a highly visceral dimension that must take into account the fact that human actors are not only cognitive beings, but are also sensual beings of flesh and blood. Our bodies, therefore, are not merely passive objects that encapsulate a mind, but also serve as active mediums of and for embodied knowledge (Turner, 2006). Insights into the world of embodied knowledge within sports, performance arts and martial arts have included studies on the lives of ballet dancers (Turner \& Wainwright, 2003; Wainwright, Williams, \& Turner, 2006); traditional martial arts from Asia (Farrer \& Whalen-Bridge, 2011); Lindy hoppers (Wade, 2011); military training in the Israeli Defence Forces (Samimian-Darash, 2012); and more recently, the phenomenon known as mixed martial arts (MMA), which has developed into a popular spectator sport (Downey, 2007; Spencer, 2009, 2014) on a global scale. Similarly, the emergence of 'fighting scholars'(Sanchez Garcia \& Spencer, 2013) - scholars in the social sciences who have continued to conduct their research within the martial arts - are often at the forefront of ethnographic and theoretical contributions within performative cultures, where the

\footnotetext{
${ }^{1}$ Dojo literally means 'Hall of the Way', or more commonly understood as the training hall among Japanese martial arts practitioners.
}

2 The real name of the organization has been withheld for confidentiality purposes. 
increasing importance of concepts such as habitus and embodiment have been fleshed out (Wacquant, 2005, 2011, 2014).

\section{Habitus and Embodiment}

A key concept employed in this paper is the habitus, which was developed by the sociologist Pierre Bourdieu, as part of Practice Theory. Long a part of cultural anthropological analysis (Ortner, 1984, p. 144-157) and often described as a theory of social action and identity construction (Bourdieu 1977, 1986; Bourdieu \& Wacquant, 1992), Practice Theory was conceived by Bourdieu to overcome what he felt to be a redundant categorical distinction in social analysis between concepts such as the 'individual' or 'social structure', and instead focuses on the complex nature of the relationship between these two concepts. This is because neither the individual nor the environment should be examined independently of each other, as social reality is far more dynamic and reflexive, reflecting a mutually influential relationship between individual choices and broader social forces. Practice Theory, therefore, seeks to transcend more static views of social action and cultural behaviours while providing, at the same time, an alternative theoretical framework and lexicon to articulate such a view.

The theory of practice as practice insists, contrary to positive materialism, that the objects of knowledge are constructed, not passively recorded, and, contrary to intellectualist idealism, that the principle of this construction is the system of structured, structuring dispositions, the habitus, which is constituted in practice and is always oriented towards practical functions. (Bourdieu, 1990, p. 52)

Subsequently, any attempt to study social reality must recognize that it possesses a practical dimension where individuals constantly communicate, interact and negotiate within existing and potential constraints exerted by a broader social structure, known in Practice Theory as the field. Social action occurs or identities are forged through the emergence of a practical sense, which is derived from personal interpretations of our relationships within corresponding environments. A useful analogy would be that of a football game, in which all social actors are situated within a 'space of play' that possesses broad rules of conduct and behaviour. Nonetheless, in spite of the rules of the game, how each player within the game performs is also dependent on their personal ability to read and interpret the game - or the logic of practice - that is embedded within our actions and the social spaces that they occur in. Over time, the individual becomes a part of 'the game' through the construction of one's habitus. In addition, once players are increasingly adept at playing 'the game', this may have an impact on the very nature of the rules, potentially influencing their interpretation or even changing them.

The habitus, then, refers to the internalized set of inclinations, behaviours, attitudes and worldviews within an individual that are often a result of the complex interplay between the subjective experiences of the individual and broader environmental forces, which may either constrain or encourage forms of thought or behaviour (Bourdieu, 1990, p. 52-65). At the same time, it is also crucial to note that the habitus does not imply rigid determinism of identity or behaviour (Wacquant, 2013a). Within the framework of Practice Theory, the habitus is a far more malleable, comprehensive and refined concept compared to the use of restrictive terms like 'individual' or 'personality', as it also articulates how each person is very much tied to the broader environment in a mutually interactive relationship. It consequently enables one to more effectively avoid the potential limitations of adopting either structuralist or phenomenological approaches to understanding social action and identity formation. For according to Bourdieu (1990, p. 55-56), 'the habitus, like every 'art of inventing', is what makes it possible to produce an infinite number of practices that are relatively unpredictable...but also limited in their diversity...because they are objectively adjusted to the logic characteristic of a particular field".

In addition, the habitus may be understood as our embodied history, a form of "internalized second nature that has been forgotten as history" (Bourdieu, 1990, p. 56). Such a view eventually recognizes the central role of how our bodies, through the process of embodiment, serve as the existential ground of the self for the formation of cultural behaviour and identity (Csordas, 1994). 
The process of embodiment is thus accomplished through carnal practices and sensual experiences that are structured around a range of flesh and blood qualities that each human possesses. For according to Wacquant (2014, p. 3), "the human animal is sentient, suffering, skilled, sedimented, and situated". Similarly within the context of this paper, a person's continued membership and participation within Clearwater Aikido Centre's community lays the foundations for the construction of an Aikido habitus. It is also where the body is both cosmos and canvas within the field of Aikido's martial and socio-cultural universe, serving as an embodied medium of meaning and becoming. This is largely due to the highly corporeal nature of social life in Aikido or the martial arts in general, and any attempt to better understand it must inevitably take into account of not only what is done to the body, but also what our bodies do.

\section{Entering the Field}

My initial contact with members of Clearwater Aikido Centre first occurred in April 2002, where I began participating in classes that were held up to six days a week. Classes from Mondays to Fridays were held in the evenings and on Saturday mornings. To further embed myself into the social environment at Clearwater, I sought employment with the head instructor and founder, Matsumoto ${ }^{3}$ sensei $^{4}$, as a non-salaried worker. As he also operated a Japanese shiatsu ${ }^{5}$ clinic that was run concurrently beside the dojo, I performed the roles of receptionist, cashier and general duties worker involving janitorial duties, cleaning the laundry, paint work and repair work to parts of the clinic and the dojo whenever necessary. This evolved into an onsite stay of several months at the dojo itself during 2003, where I inadvertently functioned as overnight caretaker of the Centre and clinic. However, due to space constraints on the part of new staff emerging on the premises, I eventually re-located my residence to a north-eastern district of Calgary by the autumn of 2004. I remained there for another year while continuing my fieldwork at the Centre and other related branches in the city.

As with all manner of ethnographic fieldwork, data collection was conducted through the process of participant observation, or more preferably in this case, participant objectivation, a term used by Bourdieu (2003). This is where the anthropologist is also reflexively a key 'object' of analysis itself, although it should be differentiated from other ethnographic accounts that have overemphasized highly discursive or textual approaches to analysis, often leading to a tendency towards a disembodied view of the world. On the other hand, while concepts such as thick participation (Samudra, 2008) have proven to be valuable in highlighting the importance of how our bodies are seen as the medium for articulating what Samudra (2008) refers to as 'kinesthetic cultures', a gratuitous overreliance on such phenomenological approaches have a tendency to only inform us more about the confessionist (Van Mannen, 2011, p. 73-100) ego-centred encounters of the anthropologist rather than the lives of the social actors within the field of study. My fieldwork sought to avoid the epistemological polemics of either of such perspectives, where

What needs to be objectivized, then, is not the anthropologist performing the anthropological analysis of a foreign world but the social world that has made both the anthropologist and the conscious or unconscious anthropology that she (or he) engages in her anthropological practice... The properties brought to light by this reflexive analysis, opposed in every respect to a self-indulgent, intimist return to the singular, private person of the anthropologist, have nothing singular and still less nothing extraordinary about them. (Bourdieu, 2003, p. 283)

It should also be mentioned that much of the inspiration for my research methodology was drawn from Wacquant's $(2005,2011,2014)$ own insights on the craft of ethnography within 'the sweet science' of boxing. In applying the concept of habitus as both 'topic and tool', my own embodied engagement at the Clearwater Aikido Centre can be seen as an attempt to put to work what Wacquant (2011, p. 87) has alternatively referred to as observant participation. It serves to

\footnotetext{
3 Matsumoto is a pseudonym for confidentiality purposes. Likewise, I have used pseudonyms to replace the actual names of my field participants throughout this paper whenever referring to them.

4 Sensei is an honorific for 'teacher' or 'instructor'

5 Shiatsu is a form of traditional Japanese finger message that also involved acupuncture.
} 
demonstrate that highly entrenched or 'nativistic' ethnographic research need not necessarily descend towards the depths of narcissistic post-structuralist attempts during field research where one's ethnographic lenses is directed either at the observer participant's own 'egological' and textual reflexivity, or in a clichéd self-defeating form of relativism that deconstructs but fails to reconstruct or re-cognize (Wacquant, 2011, p. 88-89). The task of being an observant participant into the visceral and praxeological requirements of Aikido practice, therefore, is to seek out the 'cognitive, conative and cathetic schemata' that occur within the phenomenon in question. In other worlds, the enactive ethnographer (Wacquant, 2011, 2014) may 'go native', but should also be armed, as Wacquant (2011, p. 87) has suggested, with the required methodological and theoretical weaponry that enables one to return from it a sociologist (or an anthropologist, in my case).

The ensuing discussions of my fieldwork data for this specific paper, then, are more of an attempt to outline the culmination of the various Aikido-related kinesthetic experiences of my participants rather than a pedantic effort at describing the raw details of their own somatic encounters devoid of social context. At the same time, having personally been a practitioner of Aikido before the start of my fieldwork, this certainly raises a number of methodological considerations in terms of the need for greater reflexivity on my part as ethnographer. I had already been practising Aikikai Aikido ${ }^{6}$ for several years since my undergraduate days. However, it was also one of the main reasons as to why I decided to combine my personal background in Aikido with my own doctoral research in cultural anthropology, as ethnographic study within the martial arts was still relatively uncommon during the turn of the millennium, and an as yet untapped source of rich ethnographic and theoretical insights. Although I was at best considered an intermediate practitioner ${ }^{7}$ and did not possess substantial status (i.e. as an instructor or possessing a high rank) within the larger Aikido community, such positionality, admittedly, contributed to both potential strengths and limitations in my research.

In other words, while my relative familiarity with the customs and sub-cultural practices of the martial art enabled me to adapt fairly quickly to the corporeal practices at Clearwater, it was also possibly a challenge to the way my data would be collected and interpreted, as I was in some ways, an 'insider' or a 'native', albeit still considered a foreigner ${ }^{8}$ as I was neither Japanese nor Canadian. A parallel may be drawn with Wacquant's own observations of how his own positionality as a Frenchman proved to be a 'propitious prop' for him in 'Body and Soul' (Wacquant 2004, 2005, p. 448). Such realities certainly had a distinct bearing on my own ethnographic endeavour, particularly on the nature of my membership within Clearwater and its evolving 'carnal connections' with Aikido's martial and socio-cultural world. Heeding Bourdieu's own methodological maxim of participant objectivation and Wacquant's similar stance on observant participation, this was an important caveat to be deliberated with a greater degree of selfawareness. In an attempt to bracket or minimize any presuppositions or analytical blind spots that may potentially bias my data and interpretation over the course of my fieldwork, I joined Clearwater as a total beginner while being transparent to them as a researcher who already possessed an intermediate background in Aikido.

Subsequently, the collection of data during my fieldwork was through the use of a daily field journal of my personal observations and interactions, in-depth interviews and additional documentation via video-recording and photographs. My field observations included not just the everyday interactions during training, but also a gradual insight into the personal lives of my participants in a variety of social events. It should also be clarified that my data was not simply collected in a highly compartmentalized and clinically acquired manner, nor should it be judged in similar light. The practical realities of long-term ethnographic fieldwork are far more 'untidy' and unstructured when it comes to data collection and analysis. In addition, the validity of the data I had obtained throughout this period of fieldwork is attested by my numerous interactions with the community at Clearwater and the relationships that I had built up with several of its key members, many who often clarified and corrected my observations. The ethnographic craft, in many ways, is

\footnotetext{
${ }^{6}$ Aikikai is the name of the oldest 'style' or school of Aikido that originated with the founder, Morihei Ueshiba. It is sometimes referred to as 'traditional Aikido'.

${ }^{7}$ At the beginning of my fieldwork, I held the rank of $2^{\text {nd }} k y u$, two ranks below a first degree black belt in Aikikai Aikido. 8 I am Singaporean.
} 
also a work of time, itself an embodiment of increasingly layered and nuanced observations of the ethnographer that seek to reconstruct as accurate as possible the phenomenon in question.

\section{Aikido: The Way of Harmony}

Broadly translated as 'The Way of Harmony', Aikido is a Japanese martial art that predominantly employs the use of throwing and joint-locking techniques which were inspired by traditional Japanese martial systems that utilize a comprehensive array of weaponry and grappling techniques (Long, 2001, p. 12-15). In particular, the classical jujutsu style known as Daito-ryu Aikijujutsu has been identified as a core source of Aikido's techniques as it was the style that was initially practiced by its founder, Morihei Ueshiba (Omiya, 1998). Since the official inception of the name Aikido in 1942, it has been frequently referred to as a budo, or a 'martial way', as it also seeks to transcend the practice of mere martial technique, while serving as a medium that unifies the body and mind for the aim of ethical and spiritual perfection (Murphy, 1993, p. 448-463). In addition, the most fundamental, well-known and identifiable characteristic of Aikido, by virtue of its name, is its claim to be a unique set of self-defence techniques that blend or harmonize with an attacker's force while protecting oneself and one's attacker. Consequently, its martial techniques are allegedly a metaphorical embodiment of certain philosophical and pacifist principles that its practitioners are supposed to incorporate and express through exemplary social conduct (Draeger, 1996, p. 137-162).

While it deserves a fuller discussion in its own right, it is interesting to note that the ideological and historical foundations of Aikido are closely linked to a set of syncreticized philosophical and religious beliefs drawn from various aspects of Shintoism, Buddhism, and the Omoto-kyo ${ }^{9}$ (Ooms, 1993), a Japanese religious movement that once gained significance during the early years of the twentieth century. The blending and yielding characteristics of Aikido techniques are, therefore, interpreted to embody the higher principles of interpersonal harmony and nonviolence that form a crucial component of the Aikido practitioner's martial ethos and ideology (Stevens, 1995). As a result of this, there are almost no competitions in most of Aikido's existing variant styles or different organizations ${ }^{10}$. The ideal Aikido practitioner, therefore, is someone who is expected to be well-versed in potentially lethal martial techniques but is also likened, ironically at the same time, to be an active advocate of non-violence and social reconciliation.

Within a span of over 65 years since the end of the Second World War, the practice of Aikido has spread on a global scale to most major cities in the world. The Aikikai Foundation, the oldest and largest Aikido organization at present, which the Clearwater Aikido Centre is a part of, states that Aikido is now practiced in 130 countries (Aikikai Foundation ${ }^{11}, 2014$ ). This, however, is not inclusive of other styles of Aikido which are also gaining popularity. In some ways then, the visibility and popularity of Aikido and other Japanese martial arts may be seen as part of a broader process of 'Japanization' (Iwabuchi, 2002), a transnational cultural flow that occurred in conjunction with Japan's own economic success during the post-war years. While such cultural globalization processes were partially curtailed by an extended period of economic slump in the 1990s, much of what has already been entrenched remains. Perhaps one of the strongest reasons for this has been the capacity for Japanese martial arts to be non-exclusive about their own 'cultural baggage', or what Iwabuchi has referred to as 'cultural odor' (Iwabuchi, 2002, p. 27). One need not be Japanese to pick up Aikido, but at the same time, one is also encountering and even incorporating aspects of Japanese culture in the process of participation within such cultural forms.

In recent years, anthropological or ethnographic studies that have specifically focused on Aikido have been continuously undertaken but limited in number. Some of the earliest works in the field of cultural anthropology were by Donohue (1991a, 1991b), who examined how Japanese

\footnotetext{
${ }^{9}$ Broadly translated from Japanese as the 'Teaching of the Great Origin', the Omoto-kyo was founded in 1892 by Deguchi Nao. Although still possessing followers at present, it is relatively unknown beyond Japan.

10 The most significant exception, however, would be Tomiki Ryu Aikido, or its parent organization known as Shodokan Aikido, which possesses a substantial following in Japan and other countries.

11 http://www.aikikai.or.jp/eng/information/index.html
} 
martial arts such as Aikido have played a role in creating a symbolic sense of community and identity among its members. However, it was only among subsequent scholars such as Kohn (2001, 2003) where greater analysis and discussion of the corporeal and embodied aspects of Aikido practice was given fuller attention. While Kohn (2001) observed that the Japanese origins of Aikido appeared to be irrelevant among her field participants in Northeast England, her subsequent discussion nonetheless, paradoxically, detailed an entire range of pedagogical practices that facilitated the embodiment of various forms of Japanese cultural practices in order for one to become an Aikido practitioner, highlighting once more how closely entwined the practice of Aikido remains with its cultural roots. This was even more apparent in a later article by Kohn (2008) which touched on Aikido's role in 'creatively sculpting the Self' through the use of Japanese forms of religion and cultural practices that were inherent in the martial art. In addition, it would also be useful to note that recent studies of other specific martial arts - such as Capoeira (Joseph, 2012), Jujutsu (Cohen, 2009), Vovinam (Carruthers, 1998), Pencak Silat (Wilson, 2009) and Wing Chun (Jennings, Brown, \& Sparkes, 2010) - have already noted how discourses of nationalism, religion and culture are inevitably intertwined with one's participation in them.

\section{5.- Clearwater Aikido Centre}

During the period of my fieldwork, Clearwater Aikido Centre was located in a former warehouse within an industrial district that had been refurnished and renovated into the likeness of a traditional Japanese martial arts dojo, or training hall. The Centre is best understood as an example of a loosely defined 'structure of the conjuncture' (Sahlins, 1985), where various residents from the city of Calgary and its surrounding communities in Canada have ample opportunity to encounter and interact with one another as a result of historical cross-cultural diaspora, exchange and invention. Although based in Western Canada, the Centre often exuded a diffused and hybridized sense of Japanese cultural logic that is interlaced with the varying cultural and linguistic backgrounds that each member of the dojo stemmed from. Members comprised of more than just Canadian-born White Anglophone Canadians, and originated from a variety of cultural and migrant backgrounds that ranged from parts of North and Central America, Europe, Asia and even Canadian 'First Nations' communities.

At the same time, there were also several Japanese members who were either permanent residents, on working permits, or were international students in Canada. The socio-cultural profile of the members of Clearwater Aikido Centre was predominantly reflective of a larger ethnoscape of increasingly de-territorialized and intercultural spaces, while serving at the same time as both an outpost of transnationalized Japanese-ness. The Aikido dojo existed, therefore, as a space of culture that was at the same time both relativizing and essentializing, where it sought to retain various aspects of a highly idealized portrayal of Japanese identity and practices, often framed within a larger and globalized society in Calgary. It also served as a transnational outpost for Japanese cultural identities that had become increasingly self-conscious upon arrival in Canada. This is because the practice of Aikido is often perceived by some as a cultural practice that has retained, at its core, a symbolic aura that is perceived to be unmistakably Japanese.

Although not representative of the diversity of the range of individuals that I encountered, it was also noted that the community at Clearwater Aikido Centre contained several members who were either persons pursuing higher education within tertiary institutions in Calgary, or who already possessed at least high school educational qualifications and working in so-called 'white collar' professions. While this may initially allude to suggestions that Aikido tends to appeal to persons of middle-upper socioeconomic class origins, this was not always apparent, and at best, mixed. During the time spent with them, the graduate students, corporate professionals and wealthy business persons who have turned up for class have not outnumbered the millwrights, carpenters, masseurs, cashiers or odd job workers that I have encountered. Perhaps this is revealing of the limitations of a concept such as 'class', and how the appeal of forging an Aikido habitus may transcend class differences. Similar observations were made in Abramson and Modzelweski's (2011) study of middle-class participants in MMA subcultures. Bourdieu's habitus, therefore, is felt to be able to surpass the restrictive and categorical redundancies of 'class' by an 
approach that is relational, agonistic and synthetic (Wacquant, 2013b), highlighting the varied and intersecting appeal that Aikido possesses for a wide range of persons within different cultures.

\section{6.- Acculturation and Essentialism}

The practice of Aikido at Clearwater was the site of the consumption and production of cultural practices through the body, which at the same time provided a praxeological platform and resource for either the invention or reclamation of cultural identity among many of its members. More specifically, the process of becoming and being an Aikidoka played a crucial role in cultural acculturation or cultural essentialism, where one could either construct a sense of 'Japanese-ness', which did not exist previously or to reaffirm one's primordial association with it respectively. Examples of such acculturation or essentialism could be observed among several of the Aikidoka from Clearwater Aikido Centre that I befriended during my fieldwork.

One such person was Jonathan, a man in his early twenties who was nicknamed 'Tamago' by Matsumoto sensei, the chief instructor. In spite of his white Canadian physical appearance, he was regarded by his fellow Aikidoka to possess a deep fascination and interest for Japanese culture. Hence the term tamago, which in Japanese meant 'egg', implying that although Jonathan was 'white' on the outside, he was 'yellow' inside, alluding to an 'Asian quality' about him. It was a label that Jonathan appeared to wear quite proudly, although he was also aware of the fact that Matsumoto sensei awarded this label to serve more as a form of mockery, often setting Jonathan up as an object of ridicule towards his mimetic tendencies towards 'Japanese-ness'. Although Jonathan was perhaps the exception rather than the norm when it came to such overt interest in Japanese culture and identity, the impact of Aikido's 'Japan-izing' potential was certainly not restricted to only a few members such as him.

When I first met him, Jonathan was already a highly regular practitioner at the dojo, who had turned up everyday day for classes. He quickly rose in rank, and was a $2^{\text {nd }} k y u$ (brown belt) practitioner in less than two years, a time frame considered relatively fast for one to be promoted to such a rank, which is just two levels below a first degree black belt. Jonathan also boasted that he had at least three different Japanese girlfriends within a span of two years, which he explained was a result of the fact that many white women were simply not interested in a male person of his smaller physical stature, and subsequently felt that he was neither 'masculine' nor 'manly' enough for them. Conversely, however, he admitted that it was also largely because of the sheer exoticism of his whiteness - along with his blonde hair and blue eyes - that made him attractive to Japanese women. Jonathan appeared to only listen to Japanese pop music, was taking lessons in the Japanese language, and also an avid fan of Japanese anime ${ }^{12}$ and movies. The practice of Aikido for Jonathan was concurrently an attempt to embody for himself aspects of Japanese culture that appeared to serve a purpose beyond that of martial training. Despite his own awareness of the possible incongruence that others have noted between his appearance and his 'Japanese-ness', Jonathan once confessed he was 'more Japanese' than the Japanese.

Kevin: Do you think you've become more Japanese?

Jonathan: ...in a sense, being Japanese or not...people look at skin colour, hair colour and how you act, which of course is a valid definition...but at the same time I've had Japanese people tell me that I am more Japanese than they are...so in that sense, culturally I tend to pick up certain things and certain mannerisms really naturally and automatically better than they do...while they try and tend to change that...to me it fits really well...so I mean...in that sense I am already Japanese, but whether or not I can be Japanese according to other people isn't something that I can answer anyway...but as long as you are not defining it by the idea of citizenship... ideas or...

Kevin: Appearance?

Jonathan: Yeah, so internally you know whoever you are...so if it happens to be more like this and that...that's just the way it is...

12 The common term for Japanese animation 
Jonathan's personal affinity for Japanese culture apparently allowed him to easily construct an alternate source of identity apart from his own Austrian-Canadian roots. One could argue that the intercultural identity that he had forged fulfilled a strategic purpose in gaining symbolic, social and cultural capital - non-material assets that may promote status and mobility among one's peers (Bourdieu, 1986, p. 241-258). His effective combination of 'whiteness' in appearance and 'Japaneseness' in practice also provided a useful intercultural strategy that allowed him much greater success with Japanese women who were allegedly attracted to his 'whiteness'. At the same time, it served to exoticize his own sense of selfhood among his Canadian peers for being 'Japanese on the inside', as a result of his identity as an Aikidoka.

Being an only child who regarded his own adolescence as being 'different' and somewhat awkward, Jonathan's adopted 'hybrid' cultural identity now serves as both a shield against marginalization and status symbol to gain acceptance. The ensuing habitus that he eventually constructed was situated within a unique intercultural space - that of the Aikido dojo - where he could conveniently negotiate not just between more than one cultural identity, but also between reality and imagination, as evident from his interests in Japanese anime and movies. Nonetheless, from the final remarks of the conversation, it appears Jonathan is also implicitly aware of the limits of his constructed identity. More a result of how others may seek to contradict his own physical appearance with his efforts in acculturating 'Japanese-ness', than his own professed affinity for it.

In comparison, Koichi first arrived in Canada as a landed immigrant from Japan, where he had been a chef in a restaurant, some six years before I arrived in Calgary. According to him, the main reason for moving to Canada was largely because he had married a white Canadian woman, and it was a decision made together by the two of them as they felt that they would gain greater acceptance as an ethnically-mixed couple in Canada as opposed to living in Japan. Nonetheless, the sacrifice made by Koichi to relocate because of their marriage has been fraught with difficulties and challenges, both social and occupational. Firstly, he and his wife faced resistance and rejection from his wife's family on the grounds of his different cultural background. This led to strained relations between his wife and her family, as a result of her marrying a man who was non-white and perceived as foreign or alien. At the same time, Koichi also recounted an incident when he and his wife were refused to be served when they stopped over a restaurant at a small town in Alberta, an incident that greatly unsettled both of them.

Seeking employment in Alberta had not been an easy matter for Koichi either, who decided not to continue his career as a chef but instead found a blue-collar job at a warehouse where he claimed to have been discriminated against and humiliated on the basis of his initially less than fluent command of English and his 'un-Canadian' appearance. He was harassed by colleagues at work and at times also threatened verbally, although never subjected to direct physical abuse. Koichi, therefore, wanted to seek out something that would, in his own words, 'make him stronger', and at the same time, allow him to reassert his own Japanese cultural identity. He eventually found this strength in his practice of Aikido, where the empowering and affirmative intercultural space of Clearwater not only legitimized his Japanese background with fresh symbolic capital, but the ability to face his perceived personal failure for being unable to integrate successfully in Canadian society.

Kevin: How has your experience in Canada been like?

Koichi: Always have problems. Difficult in some ways...umm...that's part of the reason I started Aikido...I was becoming Canadian...trying to be a Canadian...live like a Canadian...but every morning when I look in the mirror I see myself as being Japanese...first of all you deny...I wanna be Canadian...but you cannot deny what you are...and wake in the morning - I am Japanese...so better do something Japanese...so Aikido is Japanese...that's one of the reasons why I do Aikido...so living in Canada as a foreigner or immigrant is very difficult....white people treat me like Asian...yellow monkey...I try to be normal people...struggle all the time...that's the hardest thing...but I have to keep my identity...to stand up...I am Japanese - so what?...that's why I have to...stand up, otherwise when I turn my back around...(say) sorry I'm Japanese...(I'm) not like that anymore...

Kevin: You mean you were like that in the beginning? 
Koichi: Before I started Aikido...when I started Aikido I realized I am Japanese...I have to be...I am Japanese - so what? ... I need to get my identity back...I should be Japanese...so I thought I should do something Japanese...I cannot deny who I am.

Kevin: Do you find it hard to fit in?

Koichi: Canada... still white people's country...I can only say that much ok? But this is still white people's country...so try to fit in...try to pretend to be white people...it doesn't work...

After taking up Aikido, Koichi claimed that he was no longer intimidated as much as he had before, as he had become stronger. It appears, then, that the practice of Aikido and his newly constructed Aikidoka habitus had made a difference to his physical courage and personal selfesteem. Within a span of under three years, Koichi was promoted to the rank of $2^{\text {nd }} k y u$, similar to Jonathan's own rapid advancement. It was also interesting to note that as Koichi rose in rank, his social visibility and status at Clearwater became even greater, and eventually began to be recognized as one of Matsumoto sensei's most trusted senior students despite being relatively young in age compared to other senior members ${ }^{13}$. With his growing involvement at Clearwater, Koichi eventually left his job at the warehouse and became a full-time apprentice of Matsumoto sensei at his shiatsu clinic by late 2004. Becoming an integral part of Clearwater eventually enabled Koichi to transform his intercultural ambivalence in Canada from a potential handicap into a source of cultural pride.

While Jonathan's investment in the social, symbolic and cultural capital of Aikido provided an interesting spatial and discursive platform for the construction and maintenance of a neoJapanese persona, Koichi's own journey within Aikido's ethos appeared to be one of re-Japanization, or cultural essentialism. Both cases, then, appear to stem from different sides of the same coin. As committed practitioners of Aikido, their accounts were perhaps typical of a number of other similar cases among members at Clearwater. In this regard, one observes that the practice of Aikido was clearly more complex than the mere training of martial techniques, as it also reflected a deep commitment and personal stake that some practitioners had in their continued association with this martial art. This is because the path to becoming 'one of them' also denoted the need to construct, or reconstruct, an intercultural identity that also largely enhanced and made sense of their broader everyday lives.

At the same time, however, it would also be misleading and simplistic to assume that such Aikido habituses were attained merely through abstracted thought or belief. For it had to be practiced through one's body, together with other bodies, within a space that itself was contextualized and collusive to affect an inscriptive role upon the experience of all that were dedicated to its continued existence. This is particularly so in the context of a martial arts community. One, therefore, had to continue being there, in a visceral and corporeal sense, in order to maintain, in the long run, a belief and identity that had to be continuously inscribed through the practice of one's body. This is forged in the ongoing corporeal practices that new inductees are taught on the first day of class, such as learning how to greet other members in Japanese as you enter the premises, and performing a kneeling bow before one even steps onto the training mats.

Similar tendencies were also noted in the case of Matsumoto sensei, the founder and chief instructor of Clearwater Aikido Centre, who also served as a cultural role model for many members in the community. In our conversations, he often related how his own cultural identity as a Japanese person was intimately linked to his practice and teaching of Aikido. Already in his midfifties by the time I met him, a large part of what and how Matsumoto sensei gives meaning to his life stems largely from both his shiatsu practice and his role as a high ranking Aikido instructor, which reveals a certain deeply embedded cultural essentialism that may come across as dogmatic and uncompromising. This is once more reiterated in his firm declaration that he would never ever seek to become a citizen of Canada in spite of having lived in Calgary for more than twenty years. Neither would he, at the same time, have entertained the idea of ever practising a martial art that was clearly non-Japanese in origin.

${ }^{13}$ At the time of writing this paper, Koichi now holds a second degree black belt in Aikido and is one of the key instructors at Clearwater. 
Despite admitting that he sought a new beginning in Canada several years ago due to the pressures of everyday life in Japan, Matsumoto sensei never regarded himself to be any less Japanese in terms of cultural or national identity. One observation was that he still retained a strong 'Japanese accent' in his speech, which at times was suspected to be self-consciously deliberate. Coming from a sports-oriented family, he continually maintained strong personal links with Japan, where his siblings still resided. Aikido was obviously a clear existential anchor for him within a sea of North American everyday life. His highly regarded status and reputation among his peers, students and clients had also been largely derived and constructed from his identity as an Aikido shihan ${ }^{14}$. Matsumoto sensei, therefore, did not have to return to Japan to be Japanese, for he had re-incorporated it, in his own way, for himself, at Clearwater Aikido Centre.

Matsumoto sensei: Aikido is a Japanese martial art...if they forget about Japanese culture, they cannot learn proper Aikido.

Kevin: So...a person cannot do Aikido without Japanese culture?

Matsumoto sensei: Probably not...because that is difficult...because if many Caucasian people do that...and they teach Aikido...they go the wrong direction...

Kevin: So when you are running your own dojo and teaching Aikido, does a part of you expect your instructors to be as Japanese as you are?

Matsumoto sensei: Yeah. That's the way I would expect...

Another interesting participant was Michael, a man in his mid-thirties possessing both Japanese and English heritage. Even though he had been raised in Canada all his life, Michael describes himself as Japanese, as a result of his experiences during his youth for being regarded as 'different'. Interestingly, such an alleged difference was something that was based on his physical appearance, which alluded to facial features that could be stereotypically identified as being Asian or Native American. This factor had been a crucial part of his personal recollection of his formative years in areas such as school life, relationships with women and even employment. Michael also recalled that his grandfather, who was Japanese, had been unfairly treated and interned during the Second World War in Canada. Hence, his narrative appears to allude to a sense of historical and cultural continuity that has clearly contributed to his own perceived and defined sense of 'difference' in terms of his identity. Michael's example is, then, a good example of how physical appearances may play a part in the framing a person's own conception of the Self. His participation at Clearwater Aikido Centre may be seen as a form of identity construction or modification through the practice of his body, which serves to mediate the tension he had constantly felt all his life for being 'different'. This is in spite of the fact that Michael hardly speaks Japanese; much prefers a game of ice hockey to sumo; holds a master's degree in Engineering from the University of Calgary; is married to a white Canadian woman; and speaks English as fluently as any typical Anglophone Canadian.

Michael: ...I guess at the end of the day too...with me...being half-Japanese...I wanted to at least maintain...some of the uh...the tradition, the heritage, the culture...given that I've lacked it (chuckle)...

Kevin: So Aikido is more of a way of being Japanese for you?

Michael: To some degree...yeah, sure...it has become part of me ok...I like it...it allows me to clear my mind...you know...as with regards to the martial aspect of it...that had no influence on me selecting the art...to participate in it...Aikido...you know, now I know what it is now...it's become more important...the harmony and all that... but I think some people are there for the...'romantic' side of the martial arts...but...some people want to 'be Japanese' so bad...you know? (chuckle)...

Kevin: Has training in Aikido for the past three years affected the way you see Japanese culture?

14 Shihan is a Japanese honorific often used in martial arts for a senior level instructor. 
Michael: It has hasn't changed my view about the culture, but I want to learn more about the culture itself... umm... uhh...given that I'm third generation...and my dad can't speak the language...I can't speak the language...so much of the culture has been lost...it's this one thing that I'm trying to hang on to...on a personal level...I guess a lot of what I'm doing too is...because my upbringing was...there were really no traditions...uhh...none of that...maybe I lacked it and I wasn't taught it and I went looking for it...you also gotta remember too...I'm also very familiar to what happened to my grandfather during the war...being Japanese wasn't a good thing...you suppressed it...and it's pretty reflected in my father...you suppressed it...you know...you just try to blend into the environment...be a good citizen...be a good Canadian...don't wave the Japanese flag...cause they're gonna shoot it, right? (chuckle)...in that time... dad grew up... he got beat up badly because he's Japanese...so my upbringing was...you are a Canadian...(when) younger you feel the discrimination, cause you look different...the girls aren't quite sure of you, you know...but now you're this exotic thing, right? (chuckle)...now they pay attention...

\title{
7.- Aikido as Existential Compass and Moral Universe
}

It is, however, important to note that such observations of acculturation (or reacculturation) and cultural essentialism should not always be seen as mutually distinct examples. The ideological foundations of Aikido that were based on its para-religious origins and cultural associations have served as a draw for many who are often in search of an alternate worldview that is also perceived as a carrier of cultural authenticity. Such discourses of authenticity have already been observed in multicultural contexts such as Canada, where martial arts may serve as a form of sport-tourism (Joseph, 2008). Hence, the role that Aikido played as a means for reconstructing one's selfhood was often a critical factor in the cases of Joe, a Canadian of Filipino descent; Gary, an Anglophone Canadian of Scottish descent; and finally Nina, one of the most senior female practitioners at Clearwater, and who had been Matsumoto sensei's long-time personal assistant at his shiatsu clinic. Likening Aikido to 'a dance', Joe attributes his practice as having a profound impact on him.

\begin{abstract}
Joe: Honestly, had I not started martial arts training, I think I would have been a very different person now...Um I don't think I would have been as patient, I wouldn't have been able to have taken the risks I have in life, I wouldn't be as confident in doing the things that I do...I (probably) couldn't complete many things that I choose to do...you know... I was partying all the time...now...martial arts is an everyday thing...even when I am not training...umm it's so much a part of my personality...that all my friends that know me...understand that...my personality centres around Aikido...Aikido is so much a part of me on a daily basis...that uh....when I'm gone I'm still training... (pointing at his heart and his head) it's still here, it's still here...that's why I could be gone for a year...and I could come back and you would think that I had never left...people that see me come and go... and then all of a sudden hey...you know I'm still doing the breakfalls...there are people who go there three or four times a week and they never take the breakfalls that I did...it's such an individual thing and I apply it in every aspect of my life...whether it's business, how I deal with people, my relationships...umm...I look back...I've been training for fifteen years...I always come back...
\end{abstract}

Compared to Jonathan earlier on who appeared to privilege the 'Japanese-ness' of Aikido's cultural and symbolic capital as part of his Aikidoka persona, Joe and Gary interpreted their practice of Aikido not merely as an alternative source for status and prestige, but also as a means for the construction of a personal moral universe, combined with a sense of romanticism that has been observed in aspects of transpersonal psychological approaches to Aikido (Friedman, 2005). And although Nina claimed that Aikido was something that allowed her to 'get in there with the boys', she nonetheless asserted that she had a natural affinity, or a 'connection' with all things Japanese, mirroring similar views with those of Jonathan's. Her continued association with Aikido may be understood as an expression of her personal belief and identification with the cultural logic of an alleged sense of 'Japanese-ness' that she sought to claim for herself.

Nina: I've always... had a connection for the Japanese...always... 
Kevin: Even before Aikido?

Nina: Oh yeah...it's just something...even the thought of acupuncture...Japanese style...is so much more relaxing and a comfort to me than the Chinese style...it's just irritating...ooh...it's like their language...it's sharp to me...so I've always had a pulling towards Japan...I'd go to Japan in a heartbeat...I was using chopsticks at a young age...

To a significant extent, the continued commitment of Nina, Gary and Joe at Clearwater was largely viewed by each of them as the culmination of their individual martial or spiritual journey, or a metaphysical pilgrimage of sorts, in their personal development as human beings. The following comments by Nina similarly echo the earlier sentiments of Joe as to how Aikido has played a pivotal role in forging a sense of selfhood that is either essentialized or acculturated.

Nina: it's the one thing that's helped me with my Shiatsu very much...because we have to use our centre, our hara? Same like in Aikido...to push out from stomach, our centre...you have to have a very quiet mind...thinking love thoughts...It's shown me how to uh...how to not argue...I used to be very argumentative all the time....and now, instead of reacting...I'm listening more and then responding...that's the same type of thing as Aikido...it's like someone's attacking you...then ok...take in what they're doing...and then accept them...and then throw it away...

During my conversations with them, much attention was given to their commitment towards a highly stereotyped and culturally essentialized image of what a Japanese (or Asian) martial artist was supposed to be, which also tended to border on popular cultural imagery that Jonathan also subscribed to. Conversations regarding their continued interest in Aikido ranged from their fascination with Japanese culture, such as Nina's claim to be 'more Japanese than Canadian' from the start, and how both Gary and Joe respectively drew inspiration from portrayals of ninja and samurai in popular culture movies such as 'The Last Samurai'15 and the moral codes that they embodied. Aikido, in their opinion, provided this possible intercultural space for them to realize such a worldview with their own bodies.

Gary: And then you see a guy who's been in an art like Aikido or Ninpo...a Japanese art where is there is no attitude...everybody is so generous with knowledge and information...and patience...patience is a big thing...you know in a lot of arts...the sensei will just beat the crap out of his uke ${ }^{16}$ to show that he knows what's going and how it's done but it's not like that in Aikido...they smile at you and they make you smile while they show you the fine points...and by doing that it integrates that attitude...that positive attitude that you have to have...you have to retain everything that you learn in a positive way so that you can pass it on...cause you don't advance in these arts unless you can teach somebody who doesn't know as much as you... unless you can teach...somebody...a beginner... as much as you know...then you'll never advance...I love that about Aikido....it teaches leadership skills...it starts as a hobby and it ends as a lifestyle...

In many ways, then, the practice of Aikido was also a cultural and social resource - or an existential compass - for several of the members at Clearwater to re-imagine and construct a selffulfilling personal narrative and biography, which itself becomes real in its consequences. Much of what Aikido and the Asian martial arts represented was often viewed in diametric opposition to a definition of 'Western-ness' that was portrayed as an increasingly decadent form of 'non-culture'. The linkage between Aikido as a martial art and its cultural sources were also seen as inseparable and even highly dependent on each other. Hence, the potential loss of its cultural veneer was seen as unthinkable, or even crippling to the nature of Aikido practice itself. Echoing such sentiments is that of the teenaged Craig, who had only recently joined Clearwater at the time of my fieldwork.

Kevin: If I were to take away all this... 'Japanese-ness'...would you still continue Aikido?

\footnotetext{
${ }^{15}$ A popular Hollywood movie loosely based on historical events in 19th century Japan that was released in 2003.

16 Uke is a Japanese term used in martial arts training to refer to the person who is on the receiving end of a technique during practice.
} 
Craig: I think so...but I think it adds a lot to it...it adds a lot of character to it...well, (in) typical American and Canadian culture...we're sitting in McDonald's...we aren't exactly basking in culture...but yeah... I think that...what the Japanese background adds to it (Aikido) is very valuable...the traditions...the ceremonies...I think they add a lot to the experience...and also a lot more flexibility in the knees...it took me a couple of months to get used to it...sitting in eh...seiza...

Kevin: So you're saying that this cultural and traditional aspect cannot be separated from what you are doing?

Craig: No, I don't think so...I don't think it would be Aikido...it would be a martial art...but I don't think it would be Aikido...the traditions and the cultures inherent in Aikido are part of what that binds us...

At the same time, it should also be noted that the few Japanese women who did take part in Aikido practice regularly at Clearwater Aikido Centre revealed a markedly different agenda from the men, who often saw a link between their immutable 'Japanese-ness' and Aikido practice. In contrast, the three Japanese women that I got to know in the course of my fieldwork placed much more emphasis on the practical and exercise benefits of Aikido more than any culturally or symbolically related interests. The first two were relatively younger women - Kazuko and Mariko and had been students enrolled at the Alberta College of Art and Design and the University of Calgary respectively, and each viewed their involvement in more practical terms. Aikido was either a means of socialization and 'having something to do' (Kazuko), or a form of exercise and the learning of a skill 'to become stronger' (Mariko), although admittedly, the cultural familiarity of Aikido was a less crucial factor.

The eldest of the three, Kaoru, was married to a Japanese husband, and viewed Aikido as a means of 'taking a break' from her own personal life at work and home as a mother and wife. Taking this into consideration, such a distinction in personal reasons between the participation of men and women at Clearwater Aikido Centre reveals an important insight: the revelation that male perceptions and constructions of cultural identity appear to possess a greater stake among those who relocate themselves transnationally. Aikido, therefore, may appear to serve a more utilitarian or privatized purpose to the Japanese women at Clearwater's dojo, while the embodiment of both its martial and cultural ethos takes on a greater symbolic and even emotional dimension among its men. It might also be interesting note that all three women, at the time of writing, were engaged in successful relationships, with Kazuko and Mariko having been intimately involved with nonJapanese men, and had never mentioned it as a source of potential tension in terms of their identity or culture while living in Canada.

Kevin: We don't really have too many women in the dojo...and it's interesting when they say that Aikido is the 'way of harmony' and you don't need to use brute force or whatever...so intuitively you might think...women, who generally have less muscle mass, might be more attracted...so why do you think we see less women?

Craig: Well....I think martial arts are still viewed largely as a man's thing...you think of martial arts and you think of a man and a gi...fighting each other...mortal combat...you don't think of... women...in a hakama and a gi...fighting each other...I think there's a social aspect...we're still fairly....yeah...patriarchal in way...but eh...once women start to get involved...like today...the two new women I noticed eh...yeah one of them was here before...she came to bring the second one...once they get introduced to the environment...it's something that they can do...it's not something that matters for muscle mass...and hey like I'm a skinny guy...there's very little muscle...

\section{8.- Bodies of Culture: Becoming an Aikidoka}

Participation at Clearwater Aikido Centre's dojo was, therefore, the site of a transnational and intercultural environment where a continuous flow of reflexive and interpersonal cultural exchanges took place. At the same time, it was also a community bounded together by similarity and difference, hierarchy and egalitarianism, contrast and continuity and a social-cultural ethos 
that was ironically essentializing and relativizing at the same time. It was a dojo and a space out of place that displayed a marked sense of identity, ownership, time and boundary from the broader physical surroundings that surrounded it. In many ways, then, being a regular and dedicated member of Clearwater Aikido Centre also often meant being in a constant state of identity and cultural flux whenever one appeared at the dojo for the roughly one and a half to two hour session of practice each time. One, then, leaves Calgary, if only for a moment, into an anti-structural liminal or liminoidal space (Turner, 1987) that is betwixt and between the life-worlds of Canada and Japan. As one steps through the main entrance into the dojo each time, one's body and speech virtually reorientates itself towards the cultural game of Aikido, as the spaces within its four walls now serves as an avenue for alterity and mimesis (Taussig, 1993) through the inscriptive cultural practices that are part of Aikido training. Becoming an Aikidoka is, therefore, more than mere thought or talk, for it has to be firstly performed and believed by the body.

Michael: I'm probably...calmer...learning the limitations of the body...understanding the limitations of your mind as well...I mean there's lots of literature and talk about mind and body...it's an opportunity to learn something new everyday...it's an opportunity to try and perfect something that's unattainable...actual pure perfection does not exist...you know that...Aikido's like golf...you can never achieve a perfect swing...it's impossible...there's always some flaw...something that your body and mind aren't in tune or something...and you practice and you practice....it's a defensive type of art...it's not fighting...it's a martial art but it's defensive in nature....at the end of the day...it sounds corny...but I think Aikido chooses you, you don't choose it...

While Clearwater Aikido Centre still consciously traces its cultural and organizational roots to Japan, its members, who largely remain hyphenated Canadians from many walks of life, nevertheless, continually seek to re-define and re-invent its relevance to their own identities and lives. Existing as both a consequence and medium of a sense of interculturalism and transnationalism that has become increasingly pervasive in the last century, the cultural logic that constitutes an Aikido habitus is also a site of constant negotiation and re-imagination for those who have transplanted its practice beyond Japan, and those who seek to incorporate it within the context of Canadian society. In other words, the practice of 'Japanese-ness', although perpetuated as a necessary but not always a sufficient part of being an Aikidoka, was often propagated via bodies that were 'un-Japanese' in origin. At the same time, the practice of Aikido also contained, through its practices, an implicit re-culturalizing and re-nationalizing narrative for persons of Japanese backgrounds that is also undeniably part of a global ecumene where there are no longer distinct islands of culture (Foster, 1991; Hannerz, 1998).

Matsumoto sensei: I am Japanese. I just don't want Canadian citizenship...I don't want to give up Japanese citizenship...I feel...if I were to give up my Japanese citizenship...I lose something of myself...I would lose my identity...so that means I would be giving up everything Japanese about me...I'm Japanese, and I grew up in Japan... so that's why...my knowledge and my everything came from Japan.

Kevin: So do you think that training Aikido and teaching Aikido is connected and important to your Japanese identity?

Matsumoto sensei: Yes, that's really important...I feel like I teach...it is real Aikido...it is not like uh...like you know in other dojo... (ours is) pure Aikido.

Nonetheless, such experiences of a transnational or intercultural Aikido universe could only have been possible via the involvement of one's own corporeal self. Hence, cultural transnationalism is not something that is possible only via the imagination as suggested by other scholars (Hitchcock, 2003). Such an approach fatally neglects the vital role that the senses and the body play in the social construction of reality. Becoming a regular Aikidoka at Clearwater Aikido Centre was also largely the incorporation of the necessary dispositions and strategies of 'Japaneseness' and to tacitly recognize the possibilities of less than opaque boundaries of cultures. It also became apparent that no single Aikido dojo was ever alike in its sub-cultural practices, rituals and 
regulations, being part of a larger process of an ongoing creolization of cultural lifeworlds. Most strikingly is the variety of reasons to why people take up Aikido, which on first appearance may seem to be different, but reveal certain continuities upon closer scrutiny. A major observation here is that this can be perceived with regards to the intimate relation between the practice and use of one's body and the role it plays in the creation of one's sense of identity and place.

Such insights are further heightened particularly with regard to Aikido's less than subtle connection to an often stereotyped and essentialized notion of Japanese-ness. In addition, the continuing participation of one in the Aikido community broadly appears to be linked to the construction of a liminoidal space that allows for both the re-invention or the re-iteration of one's sense of the Self. The practice of Aikido, therefore, within a broader community of similar individuals, through the use of dress, language, narrative, and most importantly, the continued incorporation of bodily disciplines and perceptions, forms part of a comprehensive martial and socio-cultural habitus. The 'rules' or strategies that one gradually picks up along the way in becoming an Aikidoka was the gradual incorporation of a doxa of a transient and alternate identity that was manifested through the expression of speech and bodily acts, which often imitate highly stylized and stereotypical dispositions of Japanese-ness. At the same time, such practices are also reiterated within 'pure Japanese' bodies - persons of Japanese cultural origins - that are, nonetheless, encapsulated within a larger intercultural and transnational framework that often leads to a relativization of intersecting lifeworlds.

\begin{abstract}
Tim:...in my opinion, the reason that we have these...uh...these structures in the dojo...we have to learn to get along with each other...there's a very practical reason behind why we bow and stuff...it's not just trying to be polite, it's actually trying to keep order...that's where this stuff comes from...it's a society...it's Japanese society...or any society where you have a lot to people in a small space...I think you absolutely have to have that...so that it won't result in absolute anarchy...
\end{abstract}

There existed, therefore, an ongoing dialectic of negotiation and tension that constantly existed between the everyday identities of Clearwater's hyphenated Canadian members and its own Japanese members, while being framed within the alternating practical logics of being an Aikidoka and a Canadian of various ethnic or national sensibilities. The rites towards becoming an Aikidoka, or more plainly put, becoming 'one of them', is thus closely tied in with two major ritualizing and incorporative processes where one's bodily practices become a site for either alterity or the affirmation of one's cultural identity. The latter employs the practice of Aikido as a medium for consolidating a sense of cultural essentialism, while the former allows the practitioner to continually construct, experiment or invent an alternate sense of the Self. Hence, the moment one's body is dressed in keikogi and hakama ${ }^{17}$, one is no longer necessarily in Calgary, or even Canada, for the moment. At the same time, all are similarly subjected to the sensual and corporeal disciplining confines of Clearwater Aikido Centre's martial and social-cultural codes of conduct.

George: Maybe part of the attraction for me is that it lines up with my beliefs about not hurting people...being kind and helping people...maybe that's why it's such a natural fit for the Summers family...it lines up with my life's philosophy as well...about not hurting people and being helpful...and certainly sensei...umm...lives that example...

To practice Aikido and to become an Aikidoka is, therefore, not to simply engage in the continuous practice of martial techniques, but it also requires the mimetic incorporation of an entire set of bodily dispositions, corporeal rites, speech-acts and even at times, attitudes and beliefs. Like any conversion or indoctrination into any religious ideology, consequent belief and faith is never merely psychologized or idealized within a non-corporeal dimension. One is, therefore, disciplined in body and mind, although this does not necessarily translate into bodies

\footnotetext{
17 The keikogi is the traditional Japanese white clothing use for martial arts training, while the hakama is the traditional Japanese loose trousers that are worn over the keikogi. The hakama is worn by black belt holders in Aikido practice and is often either black or navy blue.
} 
that are compliant, docile or non-reflexive in extreme interpretations of Foucauldian perspectives, where the role of agency appears to be relatively more confined by the governmentality of existing social structures. Instead, one acquires a dispositional stake in the world of Aikido, more akin to a Bourdieu-ian understanding of a doxic perspective of one's place in the dojo, but also gradually develops a strategic sense of 'the game' of Aikido that enables room for the acquisition of symbolic and cultural capital.

Gary: In life...in general...absolutely every single dealing in life... if you can keep that...way of harmony, like go with the flow and staying in the moment...it works...it works with absolutely everything...you can apply it to anything...it doesn't matter if its academics, whether its sports, whether it's social interaction, absolutely anything like if you consistently keep that mindset...in general it's like being a good person, you know what I mean?... The way of harmony...is like...you could say it's the path of least resistance...

Kevin: So it's definitely sounding a lot more than just self-defence...

Gary: Yeah...definitely a lot more than self-defence...when I first got into it...I grew up in a...I grew up in an abusive home...my dad was a real alcoholic and he was really the kind of guy that threw everybody around and it was a bad situation...I think that gave me the attitude where...they say a lot of people grow up to complete the cycle...and a lot of people who grow up in abusive homes will grow up to be an abusive person...but to me it had the opposite effect...complete opposite...what it did to me was that...it showed me what I could never ever do to somebody else...or allow it to happen to somebody...one day I was in grade seven...this guy comes up to me, he runs up behind me and jump kicks in the back and tries to shove my face into this dog crap...he doesn't even know me...I was really upset of about it and I couldn't do anything about it...and I would never be the guy that would get picked on...I would never be the small guy...I always had a thing for protecting people too you know...I never want to see a woman get hit or child get hit and not do something about it because I don't think that's right...In general....anybody who cannot defend themselves should have somebody too who can defend them...so that's how I came into the martial arts...

Although not everyone will eventually remain as true believers, nor retain the level of conviction and commitment to the art, the journey for those who stay on the path and eventually become 'one of them' often entails a combination of both martial practice and the gradual inscription of Aikido's martial philosophy of 'non-violence', along with its various 'Japan-izing' practices. Aikido practice at Clearwater Aikido Centre during training sessions often involves constantly incorporating and embodying practices of being both 'Japanese' and 'martial artist' in its most ideal-typical and often stereotypical aspects. All of us who practiced in the dojo, from the moment we entered its spatial surroundings, entered not simply a place of physical labour and discipline, but also entered into a space where the social rules, or a lack of them, within a broader Canadian society, were no longer necessary applicable nor relevant.

Over time, one of the first things I noticed was that the various inscriptive and embodying rituals each person was required to learn often included a range of Japanese expressions and terminology in order to gradually become an insider. This becomes increasingly evident right from the start as one enters the dojo, when instead of the typical Anglo-Canadian greeting of 'How are ya?', one instead is expected to greet everyone in Japanese with exclamations of 'Ohaiyo Gozaimasu ${ }^{18}$ ', 'Konnichi-wa ${ }^{19}$ ' or 'Konban-wa' $w a^{20}$ ' depending on the time of day one arrived. A similar expression such as 'Sayonara' (meaning 'farewell' or 'goodbye') is once more practiced whenever anyone left the dojo. On top of the various everyday greetings and salutations in Japanese, it also included the requirement to memorize the Japanese terms for techniques, dress and equipment. Furthermore, speech and bodily acts are transformed the moment one enters the confines of the dojo such as self-conscious acts of overt bodily deference in the face of one's seniors through bowing and greeting. To enter the dojo also required a clear recalibration of one's entire bodily carriage, social skills and spoken lexicon.

\footnotetext{
18 "Good Morning" in Japanese

19 "Good Afternoon" in Japanese

20 "Good Evening" in Japanese
} 
Kevin: After doing this for six months...Do you think something about you has become a little more...Japanese?

Craig: I think so...and sometimes I find...someone comes to me and asks me and I just like "Hai!"...yeah I do....so you kinda get a little involved in it...it becomes second nature...like this 'Hai'..."How are you doing? Domo Arigato...Konnichi-wa"...the language...you kinda get wrapped up in it...it just becomes second nature...especially 'Hai' ...I noticed that a lot...the Canadian sense of nationality isn't terribly strong anyway...Canadians aren't terribly nationalistic...I think I take pride being Canadian but I don't sing "O Canada" every morning or anything like that (chuckle)...I'm Canadian...I don't feel like I've lost anything ...I think I've only gained a new outlook that is...you know...Japanese...

These acts formed part of an entire range of practices that highlighted the need for identity formation and boundary constructions that sought to actively recognize and announce one's entry into a cultural space that was distinct from another beyond the walls of the dojo. Hence, to speak these words loudly and clearly was, therefore, not simply a matter of polite address, but also the sign (or initial acknowledgement) of one's gradual incorporation into the habitus of being a member of Clearwater's martial community. Additional 'pedagogies of the body', or corporeal ritualizations, such as the removal of one's footwear; the performing of a kneeling bow at the edge of the mats before entering it; and subsequent standing bows before entering or leaving the mats all became vital practices that served as inscriptive acts of slowly honing one's senses to the requirement of becoming a member of Clearwater Aikido Centre. A person often spoke more quietly upon entry, became more self-aware of how one walked, how one sat, and even how one conducted herself or himself in relation to others. The sense of the Self is, then, often deterritorialized and de-subjectivized in the face of a heightened sense of Otherness, particularly within such a community where egotistical individualism and the disciplining of emotion and the repression of any overt reaction to physical pain or emotional outburst is constantly self-regulated and even repressed. One, then, could always come to the dojo, for at least nearly two hours at a time, to re-live and re-create another version of oneself, which would temporarily replace the other identity that existed beyond it in everyday life.

Kevin: But what is it about Aikido? Is it because you were mainly just looking for some kind of physical exercise? Or self defense skills?

\begin{abstract}
John: Well...I always wanted to learn more about self-defense and that kind of thing...I've been in some kind of fights in my life...and eh...you know...but I got to fare eh...pretty good...I didn't really like the thought of all the sparring and stuff all the time....and Aikido...you just get eh...you get some training and...you know...practice...some kind of sparring with people you know...it's a good physical workout and uh...plus it's a great workout... it's a great stress relief for me...because you know...my job is really high stress at work...and I can come in here...by the time I bow down at the mat right until the time I leave, I do not have to think about another thing outside of what's right here...until I walk back right into the change room and then there's three messages on my cellphone...
\end{abstract}

Over time, the Aikido initiate develops an increasing 'feel for the game of Aikido', where the overt and more subtle expectations of being a part of its subcultural universe inscribes itself upon the behaviours and thoughts of an Aikidoka who eventually develops a stake in the order of things. Thus, the order of things also often extended beyond the spatial confines of the dojo, 'naturalizing' themselves in seemingly trivial acts such as opening the door for Matsumoto sensei while entering a building or vehicle with him; allowing a higher-ranking practitioner to begin the practice of a technique; never publicly disagreeing with Matsumoto sensei or a senior-rank; taking the initiative to bowing first to senior practitioners; the use of Japanese terminology in speaking to each other when referring to various techniques; and even attempts at performing and assisting Matsumoto sensei in various forms of physical labour. All this is once again revealing of a set of cultural norms and dispositions that each practitioner gradually incorporates into her or his martial schema. At the same time, the practice of Aikido at Clearwater was not simply a binary practice of martiality and culture, the sacred and the profane, or the raw and the cooked, but it also existed as a field for the 
construction of habituses that allude to a sense of the past, a certain feudal martiality that at times may be seen as anachronistic to both the Japanese and non-Japanese.

Kevin: Sensei, so if I was a new person who knew nothing about Aikido and walked into the dojo and asked you, "What is Aikido?" - What would you tell me?

Matsumoto sensei: What is Aikido? Self-defence. Nobody lose. Nobody wins.

Kevin: What do you think makes a good Aikidoka?

Matsumoto sensei: Ok...First of all...dedication...in training...also they really care about their partner...training partner...and they don't force their power on their partner to make techniques work...and then loyal to sensei...that's very important to keep good relationship with student and sensei...and then good personality and be humble.

The social and cultural environment at Clearwater Aikido Centre can, then, also be understood as both a transgressive and transient space that differed sharply from the spatial scripts that lay beyond the dojo's immediate locality. It was a chronotopical spatial arena, where an intrinsic connectedness between time and space, the temporal and the spatial, and the past and present, is expressed through the body. Such an understanding is derived from the notion of the 'chronotope', first employed by Mikhail Bakhtin (1981, p. 84-258), which alludes to the interconnectedness of temporal and spatial relationships. This observation, therefore, is suggestive that the notion of culture and identity may not be as easily defined or indicated via the use of mere physiological traits, or the reductionistic and idealized reliance on conceptions of an 'imagined community'.

Correspondingly, the cultural boundaries between what may be construed to be Japanese or non-Japanese appears to rest greatly upon the continued embodied collusion and corporeal practices among the members of Clearwater Aikido Centre, as opposed to being based entirely upon either the 'colour' or 'race' of one's physical body. Nor does it entirely rely upon mere symbolic interpretation that results in the 'social construction' of an imagined or believed identity. It follows, then, that the acculturated or essentialized notions of what actually is a Japanese person, a Canadian person, an 'Asian' person or even a 'Western' person become arbitrary when one begins to understand that a culture has to be, first of all, embodied through practice. In doing so, we may, then, only see dark, fair, large, small, strong, heavy, light, soft or hard bodies - admittedly different bodies - but never self-consciously view them as different races.

The regular disciplining and practice of one's body and mind thus represents an ongoing and unending embodied rite of passage that unceasingly scripts, sculpts and sacralizes unto the Self, the dispositions and strategies of being an Aikidoka, through the body and with the body. As bodies of culture, the practice and eventual mastery of an Aikido habitus reveals to us that culture or identity cannot exist without the inscriptive role that one's body and senses must commit itself to. This is because the notion of culture is ultimately tied with one's habitus (Brightman, 1995); hence implying that culture must also necessarily possess a corporeal and embodied characteristic that is not entirely imagined. Culture must be felt, heard, smelt, tasted, seen, remembered and emoted for it is the body that ultimately serves as its existential ground (Csordas, 1990). The construction of one's Aikido habitus, for that matter then, is the gradual practice and embodiment of both the history and culture, not merely of one's own body, but also the history and culture of other bodies.

\section{References}

Abramson, C. M., \& Modzelewski, D. (2011) Caged Morality: Moral Worlds, Subculture, and Stratification among Middle-Class Cage-Fighters. Qualitative Sociology, 34(1), 143-175

Alter, J. S. (1992). The Wrestler's Body: Identity and Ideology in North India. Berkeley: University of California Press.

Bakhtin, M. M. (1981). Forms of Time and the Chronotope in the Novel. In The Dialogic Imagination: Four Essays (pp. 84-258). Austin: University of Texas.

Bourdieu, P. (1977). Outline of a Theory of Practice. Cambridge: Cambridge University Press. 
Bourdieu, P. (1986). Forms of Capital. In J. G. Richardson (Ed.), Handbook of Theory and Research in Sociology of Education (pp. 241-258). New York: Greenwood.

Bourdieu, P. (1990). The Logic of Practice. Cambridge: Polity Press.

Bourdieu, P. (2003). Participant Objectivation. Journal of the Royal Anthropological Institute. 9(2), 281-294.

Bourdieu, P., \& Wacquant, L. (1992). An Invitation to Reflexive Sociology. Cambridge: Polity Press.

Brightman, R. (1995). Forget Culture: Replacement, Transcendence, Relexification. Cultural Anthropology. 10(4), 509-546.

Brownell, S. (1995). Training the Body for China: Sports in the Moral Order of the People's Republic of China. Chicago: University of Chicago Press.

Carruthers, A. (1998). Kung Fu Fighting: The Cultural Pedagogy of the Body in the Vovinam Overseas Vietnamese Martial Arts School. The Australian Journal of Anthropology. 9(1), 45-57.

Cohen, E. B. (2009). Survival, an Israeli Ju Jutsu school of martial arts: Violence, body, practice and the national. Ethnography. 10(2), 153-183.

Crossley, M. (1995). Merleau-Ponty, the Elusive Body and Carnal Sociology. Body and Society, 1(1), 43-63.

Csordas, T. J. (1990). Embodiment as a Paradigm for Anthropology. Ethnos, 18(1), 5-47.

Csordas, T. J. (Ed.) (1994). Embodiment and Experience: The Existential Ground for Culture and Self. Cambridge Studies in Medical Anthropology: Cambridge University Press.

Csordas, T. J. (2002). Body/Meaning/Healing. New York: Palgrave Macmillan.

Donohue, J. J. (1991a). Forge of the Spirit. New York: Garland Publications.

Donohue, J. J. (1991b). The Dimensions of Discipleship: Organizational Paradigm, Mystical Transmission, Vested Interest and Identity in the Japanese Martial Arts. Ethnos, 56(1), 19-38.

Downey, G. (2007). Producing Pain: Techniques and Technologies in No-Holds-Barred Fighting. Social Studies of Science. 37(2), 201-226.

Draeger, D. F. (1996). The Martial Arts and Way of Japan: Modern Bujutsu and Budo (Vol. 3). New York and Tokyo: Weatherhill Inc.

Farnell, B. (1999). Moving Bodies, Acting Selves. Annual Review of Anthropology. 28, 341-373

Farrer, D. S., \& Whalen-Bridge, J. (2011). Martial Arts as Embodied Knowledge: Asian Traditions in a Transnational World. Albany: SUNY Press.

Foster, R. (1991) Making National Cultures in the Global Ecumene. Annual Review of Anthropology. $20,235-260$

Foster, S. L. (1995). Corporealities: Dancing Knowledge, Culture and Power. London and New York: Routledge.

Friedman, H. (2005). Problems of Romanticism in Transpersonal Psychology: A Case Study of Aikido. The Humanistic Psychologist, 33(1), 3-24

Hannerz, U. (1998). Transnational Connections: People, Culture, Places. London and New York: Routledge.

Heiskanen, B. (2012). The Urban Geography of Boxing: Race, Class and Gender in the Ring. New York and London: Routledge.

Hitchcock, P. (2003). Imaginary States: Studies in Cultural Transnationalism. Urbana and Chicago: University of Illinois.

Howes, D. (2003). Sensual Relations: Engaging the Senses in Culture and Social Theory. Ann Arbor: University of Michigan Press.

Iwabuchi, K. (2002). Recentering Globalization: Popular Culture and Japanese Transnationalism. Durham: Duke University Press.

Jennings, G., Brown, D. \& Sparkes, A. C. (2010). 'It can be a religion if you want': Wing Chung Kung Fu as a secular religion. Ethnography. 11(4), 533-557.

Jones, D. E. (Ed.) (2002). Combat Ritual, and Performance: Anthropology of the Martial Arts. Connecticut and London: Praeger.

Joseph, J. (2008) The Logical Paradox of the Cultural Commodity: Selling an "Authentic" AfroBrazilian Martial Art in Canada. Sociology of Sport Journal, 25(4), 498-515

Joseph, J. (2012). The practice of capoeira: diasporic black culture in Canada. Ethnic and Racial Studies, 35(6), 1078-1095. 
Kohn, T. (2001) Don't Talk - Blend: Ideas about the Body and Communication in Aikido Practice. In J. Hendry \& C. W. Watson (Eds.), An Anthropology of Indirect Communication (pp. 163-178). London and New York: Routledge.

Kohn, T. (2003) The Aikido Body: Expressions of Group Identities and Self-Discovery in Martial Arts Training. In N. Dyck \& E. P. Archetti (Eds.), Sport, Dance and Embodied Identities (pp. 139155). Oxford and New York: Berg.

Kohn, T. (2008). Creatively Sculpting the Self through the Discipline of Martial Arts Training. In N. Dyck (Ed.), Exploring Regimes of Discipline: The Dynamics of Restraint (pp. 99-112). New York, Oxford: Berghahn Books.

Light, R., \& Kirk, D. (2000). High School Rugby, the Body and the Reproduction of Hegemonic Masculinity. Sport, Education and Society. 5(2), 163-176.

Long, W. J. (2001). Aikido. In T. A. Green (Ed.), Martial Arts of the World: An Encyclopedia. Vol. I (pp.12-15). California, Colorado and England: ABC-CLIO.

Mascia-Lees, F. E. (Ed.) (2011). A Companion to the Anthropology of the Body and Embodiment. Oxford: Wiley-Blackwell.

Murphy, M. (1993). The Future of the Body: Explorations into the Further Evolution of Human Nature. Los Angeles: Jeremy P. Tarcher Inc.

Ooms, E.G. (1993). Women and Millenarian Protest in Meiji Japan: Deguchi Nao and Omotokyo. Cornell University East Asia Programme: University of Hawaii Press.

Omiya, S. (1998). The Hidden Roots of Aikido: Aiki Jujutsu Daitoryu. Tokyo, New York and London: Kodansha International.

Ortner, S. (1984). Theory in Anthropology since the Sixties. Comparative Studies in Society and History, 26(1), 144-160

Sahlins, M. (1985). Islands of History. Chicago and London: University of Chicago Press.

Samimian-Darash, L. (2012). Rebuilding the body through violence and control. Ethnography. 14(1), 46-63.

Samudra, J. K. (2008). Memory in our body: Thick participation and the translation of kinesthetic experience. American Ethnologist. 35(4), 665-681.

Sanchez Garcia, R., \& Spencer, D. C. (2013). Fighting Scholars: Carnal Ethnographies of Martial Arts and Combat Sports. London and New York: Anthem Press.

Spencer, D. C. (2009). Habit(us), Body Techniques and Body Callusing: An Ethnography of Mixed Martial Arts. Body \& Society. 15(4), 119-143

Spencer, D. C. (2014). Sensing Violence: An ethnography of mixed martial arts. Ethnography. 15(2), 232-254.

Stevens, J. (1995). Three Budo Masters: Jigoro Kano, Gichin Funakoshi and Morihei Ueshiba. Tokyo, London and New York: Kodansha International.

Taussig, M. (1993). Mimesis and Alterity: A Particular History of the Senses. London and New York: Routledge.

Turner, B. S., \& Wainwright, S. P. (2003). Corps de Ballet: the case of the injured ballet dancer. Sociology of Health and Illness. 25(4), 269-288.

Turner, B. S. (2006). Body. Theory, Culture and Society. 23(2-3), 223-236.

Turner, V. (1987). The Ritual Process: Structure and Anti-Structure. New York: Cornell University Press.

Van Mannen, J. (2011). Tales of the Field: On Writing Ethnography (2nd ed.). Chicago: University of Chicago Press.

Wainwright, S. P., Williams, C., \& Turner, B. S. (2006). Varieties of habitus and embodiment of ballet. Qualitative Research. 6(4), 535-558.

Wacquant, L. (2004). Body and Soul: Notebooks of an Apprentice Boxer. USA: Oxford University Press.

Wacquant, L. (2005). Carnal Connections: On Embodiment, Apprenticeship, and Membership. Qualitative Sociology. 28(4), 445-474.

Wacquant, L. (2011). Habitus as Topic and Tool: Reflection on becoming a Prizefighter. Qualitative Research in Psychology. 8(1), 81-92.

Wacquant, L. (2013a). Homines in Extremis: What Fighting Scholars Teach Us about Habitus. Body \& Society. 20(2), 3-17. 
Wacquant, L. (2013b). Symbolic Power and group-making: On Pierre Bourdieu's reframing of class. Journal of Classical Sociology. 13(2), 275-291.

Wacquant, L. (2014). For a Sociology of Flesh and Blood. Qualitative Sociology. Symposium, Fall: in press

Wade, L. (2011). The emancipatory promise of the Lindy hop, the body, and social change. Ethnography. 12(2), 224-246.

Wilson, L. (2009). Jurus, Jazz Riffs and the Constitution of a National Martial Art in Indonesia. Body and Society, 15(3), 93-119.

\section{Author's biographical data}

Kevin Siah-Yeow Tan, PhD, is a lecturer at SIM University in Singapore. He attained his PhD in Cultural Anthropology from the University of Alberta, Canada in 2008. His research interests are martial arts, religion, multiculturalism and social gerontology. E-mail: kevintan@unisim.edu.sg. 